\title{
EVALUATION OF A ${ }^{15}$ N PLOT DESIGN FOR ESTIMATING PLANT RECOVERY OF FERTILIZER NITROGEN APPLIED TO SUGAR CANE ${ }^{1}$
}

\author{
P.C.O. TRIVELIN'; W.A.R. LARA CABEZAS; R.L. VICTORIA; K. REICHARDT \\ Centro de Energia Nuclear na Agricultura - CENA/USP - C.P. 96, CEP: 13400-970, Piracicaba, SP.
}

\begin{abstract}
Two experiments were conducted on commercial sugar cane fields cropped with the variety SP70-1143, with the objective of evaluating a single row microplot design to determine plant recovery of ${ }^{15} \mathrm{~N}$ fertilizer nitrogen. One of them used ${ }^{15} \mathrm{~N}$-aqua ammonia and ${ }^{15} \mathrm{~N}$-urea applied to two linear meter microplots of a ratoon crop (four replicates). The second used one linear meter microplots (three replicates) which received ${ }^{15} \mathrm{~N}$-aqua ammonia only. The fertilizers were applied on $15 \mathrm{~cm}$ deep furrows, located $25 \mathrm{~cm}$ from both sides of the cane row. One linear meter of ratoon cane, inside and outside of the microplot, and on the same and adjacent rows were harvested twelve months after fertilization. The results indicate the feasibility of using single row segments of ratoon cane with ${ }^{15} \mathrm{~N}$ fertilizer. The main advantage of this microplot design, when compared to the classical 3 contiguous row segments, is that only one third of the labeled fertilizer is needed. In a single row, in order to separate the nitrogen taken up by plants from the fertilizer applied to the row $\left(N_{r} d f_{r}\right)$, from that applied to adjacent rows $\left(N_{r} d f_{r+1}\right.$ and $\left.N_{r} d f_{r-1}\right)$, the following should be considered: (a) a border segment of 0.5 to $1.0 \mathrm{~m}$ inside the plot, so that Ndff results from plants harvested in the center of the microplot represent the actual value of fertilizer nitrogen taken up from that applied to the same row, and (b) harvest of plants from adjacent rows at equivalent positions to those sampled inside the microplot, to quantify the ${ }^{13} \mathrm{~N}$-fertilizer uptake by outside plants $\left(\mathrm{N}_{\mathbf{r + 1}} \mathrm{dff}\right.$, and $\left.\mathrm{N}_{\mathrm{r}-1} \mathrm{dff} \mathrm{f}_{\mathrm{r}}\right)$, which is assumed to be the same as non labeled fertilizer applied to adjacent rows $\left(\mathrm{N}_{r} \mathrm{dff} \mathrm{f}_{r+1}\right.$ and $\left.\mathrm{N}_{r} \mathrm{dff} \mathrm{f}_{r-1}\right)$ taken up by inside plants. The Ndff $_{\text {toted }}$ values should be calculated by the equation: $\mathrm{Ndff}_{\text {totel }}=\mathbf{N}_{\mathbf{r}} \mathrm{dff}_{\mathrm{r}}+\mathbf{N}_{\mathrm{r}+1} \mathrm{dff}_{\mathrm{r}}+\mathrm{N}_{\mathrm{r}, \mathrm{dff}} \mathrm{d}$.

Key Words: ${ }^{15} \mathrm{~N}$, sugar cane, experimental plot design, plant recovery of fertilizer nitrogen.
\end{abstract}

\section{AVALIAÇÃo dE UM MODELO dE PARCELA COM FERTILIZANTE-15N NA DETERMINAÇÃO DO APROVEITAMENTO DO NITROGENIO DO FERTILIZANTE POR CANA-DE-AÇÚCAR}

RESUMO: Com o objetivo de avaliar um modelo de parcela, na determinaçāo do aproveitamento pela cana-deaçúcar de fertilizantes nitrogenados ${ }^{15} \mathrm{~N}$, foram conduzidos dois experimentos em áreas comerciais plantadas com a variedade SP 70-1143. Num experimento foram aplicados os adubos aquamónia- ${ }^{15} \mathrm{~N}$ e uréia- ${ }^{13} \mathrm{~N}$, em parcelas constituídas de segmentos simples de linha de soqueira de cana, com 2 metros lineares de comprimento (4 repetiç̄es). No segundo, parcelas de 1 metro linear (3 repetiç̋̄es) receberam aquamônia ${ }^{15} \mathrm{~N}$. Os fertilizantes foram aplicados em sulcos com $15 \mathrm{~cm}$ de profundidade, abertos a $25 \mathrm{~cm}$ de distáncia nos dois lados da linha de cana. Foram realizadas colheitas de 1 metro linear de cana no interior e fora das parcelas, na mesma linha e nas adjacentes à elas. Os resultados isotópicos evidenciaram ser perfeitamente possível a utilização dessas parcelas com fertilizante- ${ }^{15} \mathrm{~N}$. A principal vantagem do modelo, comparado às parcelas convencionais com 3 segmentos contíguos, 6 a redução a um terço, da quantidade de fertilizantes- ${ }^{15} \mathrm{~N}$ necessária. Na determinação do nitrogênio absorvido pelas plantas do fertilizante aplicado na linha com adubo- ${ }^{13} \mathbf{N}\left(\mathbb{N}_{r} d f_{r}\right)$, e daquele absorvido do fertilizante não marcado com o isótopo, aplicado nas linhas adjacentes $\left(\mathbb{N}_{r} \mathbf{d f}_{\mathrm{r}+1}\right.$ e $\left.\mathrm{N}_{r} \mathrm{dff}_{\mathrm{r}-1}\right)$, deve-se considerar para as parcelas em questão: (a) bordadura interna de 0,5 a $1 \mathrm{~m}$ de comprimento, para que os valores de Ndff de plantas collidas no centro delas, representem o valor maximo do nitrogennio absorvido do fertilizante aplicado na linha; e (b) colheita de plantas nas linhas imediatamente adjacentes, em posiçōes equiivalentes à efetuada no interior das parcelas, a fim de quantificar o $\mathrm{N}$ absorvido do fertilizante ${ }^{15} \mathrm{~N}\left(\mathrm{~N}_{r+1}\right.$ dff $\mathrm{f}_{\mathrm{r}} \mathrm{N}_{\mathrm{r}-1} \mathrm{dff}$ ), que representa o valor do $\mathrm{N}$ absorvido do adubo aplicado nas linhas

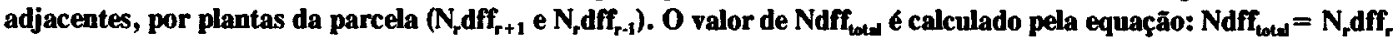
$+\mathbf{N}_{\mathbf{r}+1} \mathrm{dff}_{\mathbf{r}}+\mathrm{N}_{\mathbf{r - 1}} \mathrm{dff} \mathrm{f}_{\mathbf{r}}$

Descritores: ${ }^{15} \mathrm{~N}$, cana-de-açúcar, modelo de parcela experimental, recuperação de $\mathrm{N}$-fertilizante pela planta.

\footnotetext{
${ }^{1}$ Pesquisa desenvolvida com apoio da Cooperativa dos Produtores de Cana, Açúcar e Álcool do Estado de São Paulo COPERSUCAR, Usina São José Z.L. de Macatuba,SP e Usina Barra Grande Z.L. de Lençois Paulista,SP.

${ }^{2}$ Bolsista do CNPq.
} 


\section{INTRODUCTION}

The use of ${ }^{15} \mathrm{~N}$ tracer opens the possibility to follow and quantify this plant nutrient in different compartments of a system under study. The main advantage is that it allows the distinction, in the plant nitrogen, between soil and fertilizer $\mathrm{N}$, for instance. However, due to the high cost of the ${ }^{15} \mathrm{~N}$ labeled compounds, the size of field plots is one of the major constraints for the use of the technique.

There are examples of studies with plots varying from one single citrus plant (FEIGENBAUM et al., 1987), up to extensive areas (WENDROTH, et al, 1992) where soil spatial variability was the main focus. In most studies involving annual crops, ${ }^{15} \mathrm{~N}$ plots are small areas (microplots) with a minimum of 3 row segments, 2 to 3 meters long, placed inside larger plots fertilized at the same rate with non labeled fertilizer, used to obtain yield results. Several studies used physical barriers buried in the soil around small plots with ${ }^{15} \mathrm{~N}$-fertilizer (SAMPAIO et al., 1984; SALCEDO \& SAMPAIO, 1984b; TAKAHASHI, 1967b; WOOD, 1974). Nitrogen movement is in this way restricted to the vertical direction and lateral movement in or out of the experimental area is prevented. Although avoiding lateral $\mathbf{N}$ transport and reducing plot sizes and consequently ${ }^{15} \mathrm{~N}$ cost, it limits lateral root growth and causes an artificial porosity increasing water and solute movement at the physical interface (FOLLETT et al., 1991; SANCHEZ et al., 1987). If physical barriers are not used, careful attention should be given to plot size with reference to the border area of the effective harvesting area, taking into account horizontal $\mathbf{N}$ movement in the soil, root growth to areas outside the plot and the cost of labeled fertilizer.

Field studies with sugar cane crop have shown, under different conditions, that lateral fertilizer $\mathbf{N}$ movement might be significant (COALE \& SANCHEZ, 1990; SALCEDO \& SAMPAIO, 1984a; TAKAHASHI, 1964; TAKAHASHI, 1967a; TAKAHASHI, 1969; and TAKAHASHI, 1970).

The size of ${ }^{15} \mathrm{~N}$-fertilizer microplots was evaluated for com crop by FOLLETT et al. (1991) and for wheat by JOKELA \& RANDALL (1987), OLSON (1980) and SANCHEZ et al. (1987). The authors carried out studies without physical barriers, with plots of 2 to $4 \mathrm{~m}$ length and
1.5 to $4 \mathrm{~m}$ width (with 3 to 6 row segments inside).

SANCHEZ et al. (1987) presented a model of relative ${ }^{15} \mathrm{~N}$ enrichment distribution, for plants inside and outside labeled plots. If there is no preferential horizontal movement of $\mathrm{N}$ in the soil, plants positioned exactly on the edge of the plots (limit between plot with labeled fertilizer and outside plot with unlabeled fertilizer) should uptake half of its $\mathbf{N}$ from the plot having labeled fertilizer and half from outside, with non labeled fertilizer. Accordingly, they should have half of the value of nitrogen derived from the ${ }^{15} \mathrm{~N}$-fertilizer shown by a plant located in the center of a plot of infinite size. The authors assumed that the ${ }^{15} \mathrm{~N}$ enrichment distribution for plants across a border of labeled and non labeled areas follows a sigmoidal curve, as given by equation (1) and ilustrated in Figure 1:

$\mathrm{Y}=\left(\mathrm{Ndff}_{(\mathrm{x})} / \mathrm{Ndff}_{(\mathrm{c})}\right)=1 /[1+\exp (\mathrm{px})]$

where $Y$ is the the relative fraction of $\operatorname{Ndff} \operatorname{Ndff}_{(x)}$ is the nitrogen derived from fertilizer in plants harvested at a distance ( $x$ ) from the border of the labeled plot; $\mathrm{Ndff}_{(e)}$ is the value for plants at the center of a plot of infinite size (plants from inside the plot with no border effect of non labeled fertilizer applied outside the plot); $p$ is a parameter, constant for a given system, and (x) is the distance from the border (positive or negative, depending on plant position, outside or inside the labeled plot). The model was confirmed by SANCHEZ et al. (1987) and FOLLETT et al. (1991) on field trials with wheat and corn, respectively.

TAKAHASHI (1967a) used as experimental ${ }^{15} \mathrm{~N}$ fertilized plots, single sugar cane row segments, $3 \mathrm{~m}$ long. ${ }^{15} \mathrm{~N}$ fertilizer uptake was estimated from plants of the plot and outside plot, using plot row continuation and adjacent plot rows (row up and row down). On the other hand, JOHNSON \& KURTZ (1974) applied ${ }^{15} \mathrm{~N}$ labeled fertilizer on a $6 \mathrm{~m}$ long band, midway between corn rows spaced $76 \mathrm{~cm}$ apart, harvesting plants in adjacent rows to the labeled strip. Corn plants did not take up significant amounts of labeled $\mathrm{N}$ fertilizer from band more than one row away. Since the cost of isotope is one of the major expense in field experiments, the procedure of JOHNSON \& KURTZ (1974) had the objective of saving ${ }^{15} \mathrm{~N}$.

The minimum border size requirement for sugar cane fertility trials on Florida (USA) in 
organic soils was studied by COALE \& SANCHEZ (1990). They applied ${ }^{15} \mathrm{~N}$ labeled fertilizer $\left(\mathrm{NH}_{4} \mathrm{NO}_{3}\right)$ buried $3 \mathrm{~cm}$ beneath the surface in a 4 $m$ long band $(5 \mathrm{~cm}$ wide), midway between two rows of sugar cane planted with $1.5 \mathrm{~m}$ row spacing. The plant-cane and 1st-ratoon crops, at $2.25 \mathrm{~m}$ from the tracer source had only $6 \%$ and $1 \%$ of the ${ }^{13} \mathrm{~N}$ label at the $0.75 \mathrm{~m}$ sampling position, respectively. The authors suggested that a single border row would be sufficient for fertility trials if the levels of inter plot interference were considered tolerable.

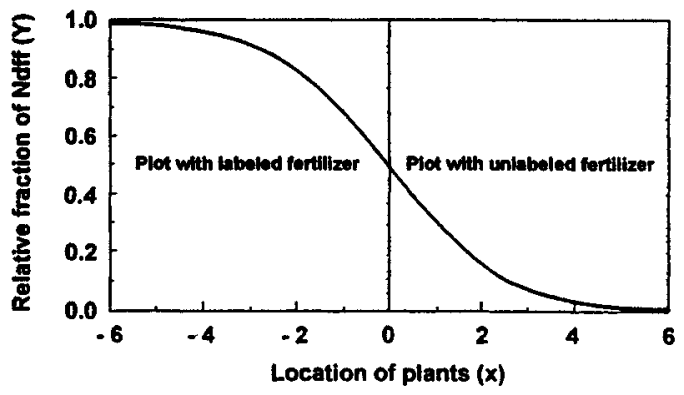

Figure 1. Relationship between relative fraction of $\mathrm{Ndff}(\mathrm{Y})$ and locations of plants $(\mathrm{x})$ near the border between plots having labeled and unlabeled fertilizer (SANCHEZ et al., 1987).

IGUE et al. (1991) estimated size and shape of field plots for sugar cane, not including border effects in their results. Nevertheless, they pointed to the need of a better definition of plot border width.

Based on the above mentioned facts and keeping in mind the high cost of ${ }^{15} \mathrm{~N}$-fertilizer, this research was carried out with the objective of defining an adequate use of ${ }^{15} \mathrm{~N}$ isotope methodology for the measurement of plant nitrogen fertilizer recovery by sugar cane, under brazilian field conditions. A microplot model consisting of a single cane row segment was evaluated to define both adequate sampling positions inside the plot and the calculations involved in the estimation of the total nitrogen in the plant derived from fertilizer ( Ndff $_{\text {(oala }}$ ), considering samples harvested inside and outside the plot.

\section{MATERIAL AND METHODS}

The experiments were conducted in two commercial sugar cane fields, planted with variety SP70-1143, on a dark red latosol, with less than $2 \%$ slope. The Usina Barra Grande (UBG) site (Lençois Paulista, SP), consisted of a first ratoon crop, and the Usina São José (USJ) site (Macatuba, SP), consisted of a second ratoon crop.

The experiment at UBG contained two treatments of nitrogen fertilizers, urea $(45 \% \mathrm{~N})$ and aqua ammonia $(18 \% \mathrm{~N})$, at a rate of $90 \mathrm{~kg} \cdot h \mathrm{a}^{-1}$ of $\mathrm{N}$. Each treatment consisted of segments of 19 neighbouring rows of sugar cane, each $10 \mathrm{~m}$ long and spaced $1.4 \mathrm{~m}$. At the center of each fourth row segment, one length of $2 \mathrm{~m}$ received ${ }^{15} \mathrm{~N}$ enriched fertilizer ( 3 atom \% ${ }^{15} \mathrm{~N}$ excess), resulting four plots (replicates) per treatment, located at the center of rows $4,8,12$ and 16 . The rest of the area for each treatment received equivalent amounts of non labeled fertilizer. Both treatments received $100 \mathrm{~m}^{3} \cdot \mathrm{ha}^{-1}$ of mixed "mosto" type vinasse, just before fertilizer application.

At USJ only aqua ammonia $(18 \% \mathrm{~N})$ was used at a rate of $100 \mathrm{~kg} \cdot \mathrm{ha}^{-1}$ of $\mathrm{N}$. The experimental area consisted of segments of 7 neighbouring rows of sugar cane, each $10 \mathrm{~m}$ long and $1.4 \mathrm{~m}$ apart. The centered $1 \mathrm{~m}$ of each second row received ${ }^{15} \mathrm{~N}$ fertilizer (3 atom \% ${ }^{15} \mathrm{~N}$ excess), resulting in 3 plots (replicates) located at the center of rows 2, 4 and 6 . The rest of the area also received non labeled aqua ammonia. Before nitrogen fertilization, $120 \mathrm{~kg}^{-h^{-1}}$ of $\mathrm{K}_{2} \mathrm{O}$ as $\mathrm{KCl}$ were applied.

Soil tillage between rows, as recommended by RODRIGUES et al. (1984), was carried out in both experiments just before fertilizer applications. The fertilizers (labeled and unlabeled fertilizers-N for UBG and USJ, and $\mathrm{KCl}$ at USJ experiment) were manually distributed and buried to the $15 \mathrm{~cm}$ soil depth in furrows spaced $25 \mathrm{~cm}$ from both sides of all row segments.

Both experiments started in 1984. Plant shoot samples from $1 \mathrm{~m}$ of sugar cane row were harvested after twelve months, without burning, including the trash (dry leaves). At UBG five samples per replicate, at positions A, B, C, D and $E$ as shown in Figure 2, were taken. The average distances from the center of the plot $(O)$ were 0.25 ; 0.75 and $1.25 \mathrm{~m}$ respectively for $A$ to $C$, and $1.42 \mathrm{~m}$ for samples $D$ and $E$. Samples A and B were inside the labeled plot, and samples C, D and E were out- 
side. The experiment at USJ had a similar sampling scheme (Figure 3), resulting for each replicate, in one sample inside plot and four outside.

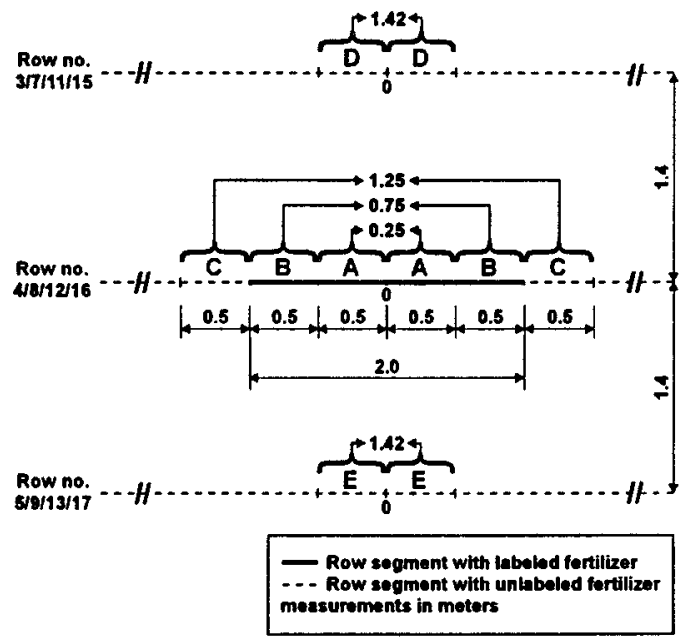

Figure 2. Location of plant sampling for Usina Barra Grande (UBG) experiments.

After measuring fresh matter yield (including trash), the plants were chopped and subsampled. After oven drying to constant mass at $65^{\circ} \mathrm{C}$ and grinding to 50 mesh size $(<0.4 \mathrm{~mm})$ in a Wiley mill, nitrogen content by Kjeldahl digestion-distillation $(\% \mathrm{~N})$ and ${ }^{15} \mathrm{~N}$ abundance (atom \% ${ }^{15} \mathrm{~N}$ excess) by mass spectrometry (TRIVELIN et al., 1973), were performed. Plant moisture content was also determined and was used to calculate dry matter yield. The conversion factor of 7,143 (total length of rows in 1 ha of $1.4 \mathrm{~m}$ spaced sugar cane) was used to express the data on hectare basis. Nitrogen in the plant derived from fertilizer (Ndff), on \% and kg.ha ${ }^{-1}$ was calculated from ${ }^{15} \mathrm{~N}$ abundance data (atom $\%{ }^{15} \mathrm{~N}$ excess) and total nitrogen in cane shoot $\left(\mathrm{kg} \cdot \mathrm{ha}^{-1}\right)$, using the expressions:

$\operatorname{Ndff}(\%)=(a / b) \cdot 100$

$\operatorname{Ndff}\left(\mathrm{kg}_{\mathrm{g}} \cdot \mathrm{ha}^{-1}\right)=[\mathrm{Ndff}(\%) / 100] \cdot \mathrm{TN}$

where $\mathrm{a}$ e b are the ${ }^{15} \mathrm{~N}$ abundance (atom $\%{ }^{15} \mathrm{~N}$ excess) of plant and fertilizer, respectively; $\mathrm{TN}$ is the total nitrogen accumulated in cane shoot $\left(\mathrm{kg} \cdot \mathrm{ha}^{-1}\right)$.

As an approximation to the SANCHEZ $e t$ al. (1987) model (equation 1), theoretical values of $\mathrm{Ndff}_{(\mathrm{c})}$ for each plot were calculated according to expression 4:

$$
\mathrm{Ndff}_{(c)}=\mathrm{Ndff}_{(e)}+\operatorname{Ndff}_{(e)}
$$

$\mathrm{Ndff}_{(c)}$ is the nitrogen in the plant derived from fertilizer-N for canes from inside plot with no border effect of non labeled fertilizer applied to the row outside the plot; (e) and (-e) designate neighbour samples at symmetric positions outside and inside of the edge of the microplot, respectively.

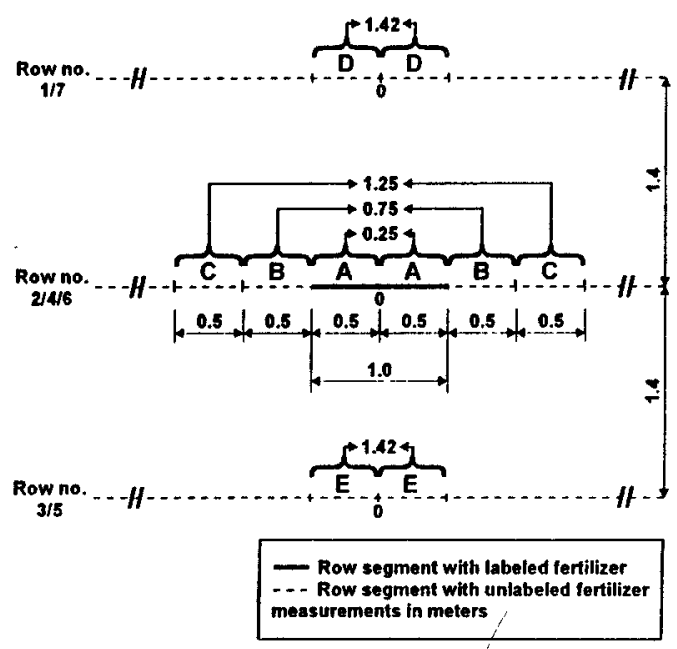

Figure 3. Location of plant sampling for Usina São José (USJ) experiment.

Data were analysed using the Tukey test at $5 \%$ probability level and Student paired $t$ test, to compare means. A linear approximation to the Sanchez'model was used. Linear regression analysis of Ndff for samples A, B and C (as dependent variable) against distances was used in both experiments to estimate the distances $\left(\mathrm{x}_{\mathrm{Nddf}}\right)$ from the center $(O)$ of the plot where $\mathrm{Ndff}_{(c)}$ values should be obtained. Thus, the theoretical border widths $\left(W_{b}\right)$ could be calculated from the difference of half plot size and the distance from center, that is: $W_{b}=1-x_{\text {Naffe }}$, and $W_{b}=0.5-x_{\text {Naffe }}$, for UBG and USJ experiments, respectively. 


\section{RESULTS AND DISCUSSION}

TABLES 1 and 2 show yield data for UBG and USJ, respectively. Mean values for canes at different distances from plot center (within and outside plot) did not show significant statistical differences.

The effect of the distance from plot center (canes inside and outside plot) on Ndff (\% and $\mathrm{kg} . \mathrm{ha}-1$ ) is clear in TABLE 3 . In general, Ndff decreased with distance from the center of the labeled plot, as expected. Some fluctuations are however observed, which are the result of plot length, distance from labeled border, root distribution, soil variability. Ndff for adjacent rows (row up and row down) at UBG did not differ statistically, which indicates no preferential lateral $\mathrm{N}$ movement in the soil. The results also show that plants from one row absorb fertilizer from adjacent rows. Therefore, when this experimental design is used, assuming no preferential lateral nitrogen movement by mass flow, the Ndff for plants of adjacent rows of the plots should be added to the Ndff for plot plants of the labelled row, when calculating total fertilizer use by the crop ( $\mathrm{Ndff}_{\text {toal }}$ ). For experimental plots with three or more rows of labeled fertilizer (e.g.: JOKELA \& RANDALL, 1987 and FOLLETT $e t$ al.,1991), the Ndff from plants of the central row represents the total fertilizer nitrogen absorbed (from the row itself, plus adjacent rows), and it is not possible to estimate the nitrogen uptake by plants from the fertilizer applied in adjacent rows.

At UBG, the average fresh and dry matter yields, and the total nitrogen for both urea and aqua ammonia treatments (TABLE 1) were not statistically different. The same was true for Ndff for both sources of fertilizer N (TABLE 3). Those are strong evidences that sugar cane productivity and plant recovery of fertilizer $N$ were not influenced by the nitrogen fertilizer source, as was also observed by PENNA \& FIGUEIREDO (1984), and TRIVELIN et al. (1986).

Calculated values of $\mathrm{Ndff}_{(\mathrm{c})}(\%$ and $\mathrm{kg}$. $\mathrm{ha}^{-1}$ ) are shown in TABLE 4. The values for $\mathrm{Ndff}_{(\mathrm{c})}$ and $\mathrm{Ndff}_{(0.25)}$ at UBG did not differ significantly from each other using the $t$ test, for both urea and aqua ammonia treatments (TABLE 5). This indicates that Ndff results from the central meter of $2 \mathrm{~m}$ long plots represent the total $\mathrm{N}$ uptaken by plants from the fertilizer applied to the same row. On the other hand, plants farther from the center of the labeled plot showed significantly different Ndff values. TABLE 5 also shows that $\mathrm{Ndff}_{(0.25)}$ represents at least $90 \%$ of the calculated $\mathrm{Ndff}_{(\mathrm{c})}$ values; for aqua ammonia and urea treatments.

TABLE 1. Fresh matter and dry matter yields and total nitrogen accumulated in cane shoot including the trash (dry leaves) for UBG experiments (averages for four replicates).

\begin{tabular}{cccccccccc}
\hline \hline $\begin{array}{c}\text { Distance from } \\
\text { plot center } \\
\mathrm{m}\end{array}$ & \multicolumn{3}{c}{ Fresh Matter } & \multicolumn{3}{c}{ Dry Matter } & \multicolumn{3}{c}{ Total Nitrogen } \\
\cline { 2 - 10 } & urea & aqua & mean & urea & aqua & mean & urea & aqua & mean \\
\hline $0.25^{(1)}$ & 149 & 139 & $144 \mathrm{a}$ & 60.1 & 56.7 & $58.4 \mathrm{a}$ & 252 & 249 & $250 \mathrm{a}$ \\
$0.75^{(1)}$ & 94 & 157 & $125 \mathrm{a}$ & 37.6 & 62.7 & $50.1 \mathrm{a}$ & 153 & 266 & $210 \mathrm{a}$ \\
$1.25^{(1)}$ & 139 & 140 & $139 \mathrm{a}$ & 54.1 & 54.5 & $54.3 \mathrm{a}$ & 220 & 233 & $227 \mathrm{a}$ \\
row up & 172 & 180 & $176 \mathrm{a}$ & 67.5 & 69.5 & $68.5 \mathrm{a}$ & 277 & 292 & $285 \mathrm{a}$ \\
$1,42^{(2)}$ & & & & & & & & & \\
row down & 159 & 158 & $159 \mathrm{a}$ & -63.1 & 60.7 & $61.9 \mathrm{a}$ & 256 & 259 & $258 \mathrm{a}$ \\
mean & $142 \mathrm{a}$ & $155 \mathrm{a}$ & & $56.5 \mathrm{a}$ & $60.8 \mathrm{a}$ & & $232 \mathrm{a}$ & $260 \mathrm{a}$ & \\
CV\% & & 26 & & & 24 & & & 25 & \\
\hline \hline
\end{tabular}

(1) Average distances of the samples harvested on microplot row from the center $(0)$ of the plot.

(2) Average distances of the samples collected on adjacent microplot rows (row up and row down) from the center $(O)$ of the plot.

Means with the same letter are not significantly different by Tukey test $(p=0.05)$ 
TABLE 2. Fresh matter and dry matter yields and total nitrogen in cane shoot including the trash (dry leaves) for USJ experiment (averages for three replicates for samples harvested on microplot rows and four replicates for samples collected on adjacent microplot rows).

\begin{tabular}{cccc}
\hline \hline $\begin{array}{c}\text { Distance from microplot } \\
\text { center } \\
\mathrm{m}\end{array}$ & Fresh Matter & Dry Matter & Total Nitrogen \\
\hline $0.25^{(1)}$ & t.ha & kg.ha $^{-1}$ \\
\hline $0.75^{(1)}$ & $150 \mathrm{a}$ & $\mathrm{t}^{-1} \mathrm{ha}^{-1}$ & $131 \mathrm{a}$ \\
$1.25^{(1)}$ & $163 \mathrm{a}$ & $38.5 \mathrm{a}$ & $161 \mathrm{a}$ \\
$1.42^{(2)}$ & $145 \mathrm{a}$ & $41.1 \mathrm{a}$ & $155 \mathrm{a}$ \\
mean & $146 \mathrm{a}$ & $43.1 \mathrm{a}$ & $144 \mathrm{a}$ \\
$\mathrm{CV} \%$ & 150 & $37.6 \mathrm{a}$ & 148 \\
\hline \hline
\end{tabular}

(1) Average distances of the samples harvested on microplot row from the center (O) of the plot.

(2) Average distances of the samples collected on adjacent microplot rows (row up and row down) from the center $(O)$ of the plot.

Means with the same letter are not significantly different by Tukey test $(p=0.05)$

TABLE 3. Nitrogen in the plant derived from fertilizer $\left(\operatorname{Ndff}_{(x)}\right)$ in cane shoot including the trash (dry leaves) for UBG and USJ experiments.

\begin{tabular}{cccccccccc}
\hline \hline \multirow{2}{*}{$\begin{array}{c}\text { Distance from } \\
\text { plot cenier }\end{array}$} & \multicolumn{4}{c}{ Usina Barra Grande Experiment } & \multicolumn{3}{c}{ U.S.J. Exper. } \\
\cline { 2 - 9 } $\mathrm{m}$ & urea & aqua & mean & urea & aqua & mean & \multicolumn{2}{c}{ aqua ammonia } \\
\hline $0.25^{(1)}$ & 11.23 & 10.23 & $10.73 \mathrm{a}$ & 28.4 & 25.8 & $27.1 \mathrm{a}$ & $7.47 \mathrm{a}$ & $9.7 \mathrm{a}$ \\
$0.75^{(1)}$ & 8.64 & 7.22 & $7.93 \mathrm{~b}$ & 12.7 & 18.4 & $15.6 \mathrm{~b}$ & $5.19 \mathrm{~b}$ & $8.4 \mathrm{~b}$ \\
$1.25^{(1)}$ & 3.79 & 4.04 & $3.92 \mathrm{c}$ & 8.4 & 9.5 & $9.0 \mathrm{c}$ & $1.02 \mathrm{c}$ & $1.6 \mathrm{c}$ \\
& 1.91 & 1.86 & $1.89 \mathrm{~d}$ & 5.4 & 5.5 & $5.5 \mathrm{c}$ & & \\
$1.42^{(2)}$ & & & & & & & $1.62 \mathrm{c}$ & $2.2 \mathrm{c}$ \\
row up down & 1.93 & 1.14 & $1.54 \mathrm{~d}$ & 5.1 & 3.1 & $4.1 \mathrm{c}$ & & \\
mean & $5.50 \mathrm{a}$ & $4.90 \mathrm{a}$ & & $12.0 \mathrm{a}$ & $12.5 \mathrm{a}$ & & 3.83 & 5.5 \\
CV\% & & 20 & & & 35 & & 17 & 14 \\
\hline \hline
\end{tabular}

(1) Average distances of the samples on microplot row from the center (O) of the plot (4 and 3 replicates for UBG and USJ experiments, respectively).

(2) Average distances of the samples collected on adjacent microplot rows (row up and row down) from the center $(O)$ of the plot; 4 replicates for UBG and USJ experiments.

Means with the same letter are not significantly different by Tukey test $(p=0.05)$ 
TABLE 4. Theoretical values of $\mathrm{Ndff}_{(\mathrm{c})}$, linear regressions between $\mathrm{Ndff}_{(\mathrm{x})}$ values (\% and kg.ha $\left.{ }^{-1}\right)$ and the distance from microplot center for plants collected on plot row, and theoretical border plot widths $\left(\mathrm{W}_{\mathrm{b}}\right)$.

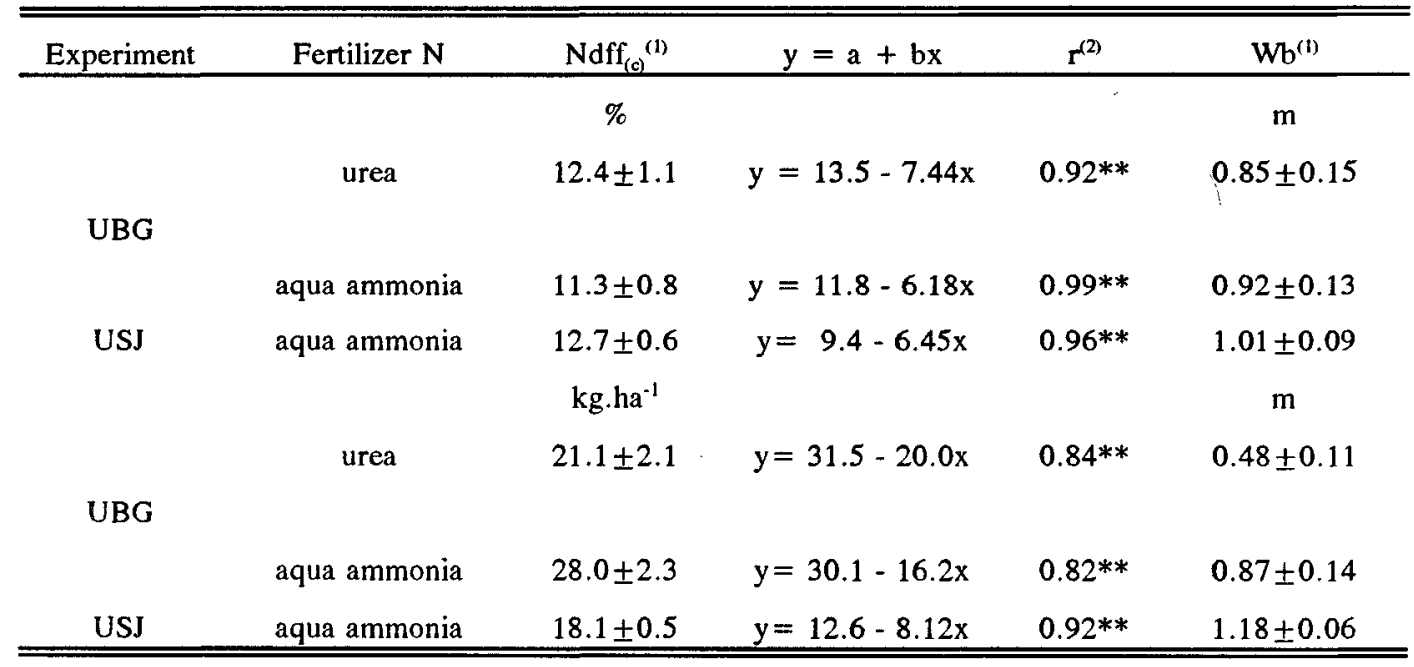

(1) Mean and standard error ( $m \pm s e)$, with $n=4$ and $n=3$ for UBG and USJ experiment, respectively.

(2) Correlation coefficient; double asterisk $(* *)$ means significantly high correlation coefficient $(r)$ at $1 \%$ probability level by $\mathrm{F}$ test.

For the USJ experiment, $\mathrm{Ndff}_{(0.25)}$ represented only $59 \%$ of the $\mathrm{Ndff}_{(\mathrm{c})}$ and those values differed significantly by the $t$ test (TABLE $5)$. In this case, all plants from the labeled plot ( $1 \mathrm{~m}$ length) were sampled. Nevertheless, this plot design may be used when other samples at symmetric positions outside the microplot and close to its border are also collected.

They can be used to calculate the theoretical $\mathrm{Ndff}_{(\mathrm{c})}$ values for fertilizer $\mathrm{N}$ applied to plot row, according to equation 4 . This kind of microplot design can also be used in the procedures as performed by TAKAHASHI (1967a), who harvested all plot and neighbour plants, from the same and adjacent rows, to determine $\mathrm{Ndff}_{\text {total }}$.

The linear regressions shown in TABLE 4 , all with significantly high correlation coefficients (r), were used to estimate border widths $\left(\mathrm{W}_{\mathrm{b}}\right)$, which define the useful harvesting area, inside the microplot, to calculate $\mathrm{Ndff}_{(c)}$ values. The results (TABLE 4) indicate ideal border widths on the order of $1 \mathrm{~m}$. On the other hand, for UBG expeririment, $0.5 \mathrm{~m}$ border width would be adequate for plants collected in the central $1 \mathrm{~m}$ (TABLE 5).

The model of microplot consisting of single sugar cane row segments with ${ }^{15} \mathrm{~N}$-fertilizer has advantages and may be used when $\mathbf{N}$ is banded, and only plant uptake (Ndff) is to be measured.
Further studies are necessary before applying the concept to broadcast $\mathrm{N}$. It should be pointed out, however, that this microplot design is not suitable to measure residual fertilizer effect or field $\mathrm{N}$ balance studies.

In this experiment, $\mathrm{N}$ uptake in sugar cane crop is given by the direct technique of determination of ${ }^{15} \mathrm{~N}$-labeled fertilizer in the plant shoot. $\mathrm{N}$ uptake values by the indirect method where differences are calculated between fertilized and non fertilized treatments, are not here reported. It was found, as have others, that the direct method is both more sensitive and precise than the indirect technique in field experiments with sugar cane. Nevertheless, the ${ }^{15} \mathrm{~N}$ technique has various possible inaccuracies due to soil processes such as mineralization-immobilizationturn-over(JANSSON \& PERSSON, 1982), or due the substitution of ${ }^{15} \mathrm{~N}$ by ${ }^{14} \mathrm{~N}$, when the labeled $\mathrm{N}$ acts as a substitute for unlabeled soil $\mathrm{N}$ that otherwise would have been substracted from the pool during processes such as immobilization and denitrification (JENKINSON $e t$ al., 1985).

Furthermore, the addition of $\mathrm{N}$ fertilizer to the soil could stimulate the uptake of native soil $\mathrm{N}$ via priming effect (HAUCK \& BREMNER, 1976), termed by JENKINSON et al. (1985) "added nitrogen interation" (ANI). 
TABLE 5. Comparison of percentage of $\mathrm{N}$ in plant derived from fertilizer $\left(\mathrm{Ndff}_{(\mathrm{x})}\right)$ from samples collected on microplot rows with theoretical Ndff $f_{(c)}$ values, and $\mathrm{Ndff}_{(x)} / \mathrm{Ndff}_{(c)}$ ratios $\left(\mathrm{R}_{\mathrm{x} / \mathrm{c}}\right)$ for UBG and USJ experiments.

\begin{tabular}{|c|c|c|c|c|c|c|c|c|c|}
\hline \multirow{4}{*}{$\begin{array}{c}\text { Distance } \\
\text { from } \\
\text { plot } \\
\text { center } \\
\text { m }\end{array}$} & \multicolumn{6}{|c|}{ UBG Experiment } & \multirow{2}{*}{\multicolumn{3}{|c|}{$\begin{array}{l}\text { USJ Experiment } \\
\text { aqua ammonia }\end{array}$}} \\
\hline & \multicolumn{3}{|c|}{ aqua ammonia } & \multicolumn{3}{|c|}{ urea } & & & \\
\hline & $\operatorname{Ndff}_{(x)}(1)$ & $p^{(2)}$ & $\mathbf{R}_{x / c}$ & $\operatorname{Ndff}_{(x)}(1)$ & $p^{(2)}$ & $\mathbf{R}_{x / c}$ & $\operatorname{Ndff}_{(x)}(1)$ & $p^{(2)}$ & $\mathbf{R}_{\mathrm{x} / \mathrm{c}}$ \\
\hline & $\%$ & & & $\%$ & & & $\%$ & & \\
\hline 0.25 & $10.2 \pm 0.74$ & 0.25 & 0.91 & $11.2 \pm 0.37$ & 0.38 & 0.90 & $7.47 \pm 0.66$ & 0.00 & 0.59 \\
\hline 0.75 & $7.22 \pm 0.65$ & 0.00 & 0.64 & $8.64 \pm 1.02$ & 0.04 & 0.70 & $5.19 \pm 0.17$ & 0.00 & 0.41 \\
\hline 1.25 & $4.04 \pm 0.14$ & 0.00 & 0.36 & $3.80 \pm 0.46$ & 0.03 & 0.31 & $1.02 \pm 0.28$ & 0.00 & 0.08 \\
\hline
\end{tabular}

(1) Mean and standard error ( $m \pm s e)$ with $n=4$ and $n=3$ for UBG and USJ experiment, respectively.

(2) Probability level by paired $t$ test: $\mathrm{Ndff}_{(x)}$ versus $\mathrm{Ndff}(())$.

A complementary study would be desirable in future using a large labeled area to compare the results with the recommended ${ }^{15} \mathrm{~N}$ fertilizer single row segments. It would be also desirable to include plots and harvests of non fertilized areas, so that the difference method could be compared.

\section{CONCLUSIONS}

The results suggest that it is possible to perform field studies using ${ }^{15} \mathrm{~N}$-fertilizer single row segments of ratoon cane, to determine fertilizer nitrogen recovery by the crop. As an advantage, this microplot design uses one third of the labeled isotope used in conventional designs. Total plant nitrogen derived from fertilizer ( $\mathrm{Ndff}_{\text {toonl }}$ ) can be estimated from ${ }^{15} \mathrm{~N}$ abundance in plants harvested from the same and adjacent rows, inside and outside microplots. To evaluate separately the nitrogen taken up by plants from the fertilizer applied to the row itself $\left(\mathrm{N}_{\mathrm{r}} \mathrm{dff} \mathrm{f}_{\mathrm{r}}\right)$, from that applied to adjacent rows $\left(\mathrm{N}_{\tau} \mathrm{dff}_{r+1}\right.$ and $\left.\mathrm{N}_{r} \mathrm{dff}_{\mathrm{r}-1}\right)$, the following has to considered: (a) a border segment of 0.5 to $1.0 \mathrm{~m}$ length, in order to guarantee that Ndff results from plants harvested in the center of the microplot represent the maximum value of fertilizer nitrogen taken up by plants, originated from the fertilizer applied to the same row $\left(\mathrm{N}_{\mathbf{r}} \mathrm{dff} \mathrm{r}_{\mathrm{r}}\right.$; (b) harvest of plants from adjacent rows in positions equivalent to samples from inside the microplot, with the objective of quantifying the ${ }^{15} \mathrm{~N}$-fertilizer $\left(\mathrm{N}_{\mathrm{r}+1} \mathrm{dff} \mathrm{r}_{\mathrm{r}}\right.$ and $\left.\mathrm{N}_{\mathrm{r}-1} \mathrm{dff} \mathrm{f}_{\mathrm{r}}\right)$ taken up by plants from outside plot, which represents the same amount of non labeled fertilizer applied to adjacent rows $\left(\mathrm{N}_{\mathrm{r}} \mathrm{dff} \mathrm{f}_{\mathrm{r}+1}\right.$ and $\left.\mathrm{N}_{\mathrm{r}} \mathrm{dff}_{\mathrm{r}-\mathrm{l}}\right)$ taken up by inside plot plants. In a field experiment the Ndff toal value of each replicate should be calculated by the equation (5):

$$
\mathrm{Ndff}_{\text {towal }}=\mathrm{N}_{r} \mathrm{dff}_{\mathrm{r}}+\mathrm{N}_{r+1} \mathrm{dff} \mathrm{f}_{\mathrm{r}}+\mathrm{N}_{r-1} \mathrm{dff} \mathrm{f}_{\mathrm{r}}
$$

\section{ACKNOWLEDGMENTS}

We thank J.T. Coleti and J.C.S. Rodrigues, agronomists from Usina São José and COPERSUCAR, respectively, for their assistance in the field work.

\section{REFERENCES}

COALE, F.J.; SANCHEZ, C.A. Effective distance of nutrient acquisition for sugarcane grown on everglades histosols. Joumal American Society of Sugar Cane Technology, Belle Glade, v.10, p.39-44, 1990.

FEIGENBAUM, S.; BIELORAI, H.; ERNER, Y.; DASBERG, $S$. The fate of ${ }^{15} \mathrm{~N}$ labeled nitrogen applied to mature citrus trees. Plant and Soil, The Hague, v.97, n.2, p.179-187, 1987.

FOLLETT, R.F.; PORTER, L.K.; HALVORSON, A.D. Border effects on nitrogen-15 fertilized winter wheat microplots grown in the great plains. Agronomy Journal, Madison, v.83, n.3, p.608-612, 1991.

HAUCK, R.D.; BREMNER, J.M. Use of tracers for soil and fertilizer nitrogen research. Advances in Agronomy, New York, v.28, p.219-266, 1976. 
IGUE, T.; ESPIRONELO, A.; CANTARELLA, H.; NELLI, E.J. Tamanho e forma de parcela experimental para cana-de-açúcar. Bragantia, Campinas, v.50, n.1, p.163-180, 1991.

JANNSON, S.L.; PERSSON, J. Mineralization and immobilization of soil nitrogen. In: STEVENSON, F.J. (ed). Nitrogen in agricultural soils. Madison: American Society of Agronomy, 1982. p.229-252. (ASA. Monograph, 22).

JENKINSON, D.S.; FOX, R.H.; RAYNER, J.H. Interations between fertilizer nitrogen and soil nitrogen - the so-called 'priming' effect. Journal of Soil Science, Oxford, v.36, n.3, p.425-444, 1985.

JOKELA, W.E.; RANDALL, G.W. A nitrogen-15 microplot design for measuring plant and soil recovery of fertilizer nitrogen applied to corn. Agronomy Journal, Madison, v.79, n.2, p.322-325, 1987.

JOHNSON, J.W.; KURTZ, L.T. A technique for reducing ${ }^{i s} \mathrm{~N}$ required for field experiments with labeled nitrogen fertilizer. Soil Science, Baltimore, v.117, n.6, p.315-317, 1974.

OLSON, R.V. Plot size requirements for measuring residual fertilizer nitrogen and nitrogen uptake by corn. Soil Science Society of America Journal, Madison, v.44, n.2, p.428-429, 1980.

PENNA, M.J.; FIGUEIREDO, A.A.M. Aquamônia $x$ uréia em soqueiras de cana-de-açúcar fertilizadas com vinhaça. In: SEMINÁRIO DE TECNOLOGIA AGRONÔMICA, 2., 1982. Piracicaba. Anais... São Paulo: COPERSUCAR, 1984, p.180-195.

RODRIGUES, J.C.S.; PENNA, M.J.; MORAES, R.S. Complementação nitrogenada em áreas fertilizadas com vinhaça. In: REUNIĀO TÉCNICA AGRONÔMICA: manejo e adubação na cultura da cana-de-açúcar, 3., 1984. Piracicaba. Piracicaba: COPERSUCAR, 1984. p.33-39.

SALCEDO, I.H.; SAMPAIO, E.V.S.B. Dinâmica de nutrientes em cana-de-açúcar. II. Deslocamento vertical e horizontal de $\mathrm{NO}_{3}^{-}-\mathrm{N}$ e $\mathrm{NH}_{4}{ }^{-}-\mathrm{N}$. Pesquisa Agropecuária Brasileira, Brasília, v.19, n.9, p.1103-1108, 1984a.

SALCEDO, I.H.; SAMPAIO, E.V.S.B. Eficiência de utilização de uréia- ${ }^{15} \mathrm{~N}$ pela cana-soca em tabuleiro costeiro de Pernambuco. In: SEMINÁRIO REGIONAL SOBRE TÉCNICAS NUCLEARES NA PRODUÇĀO DE PLANTAS AGRÍCOLAS. 1984, Piracicaba. Anais... Piracicaba: CENA, 1984b, p.205-209.

SAMPAIO, E.V.S.B.; SALCEDO, I.H.; BETTAMY, J. Dinâmica de nutrientes em cana-de-açúcar. 1 . Eficiência de utilização de uréia- ${ }^{13} \mathrm{~N}$ em aplicaçāo única ou parcelada. Pesquisa Agropecuária Brasileira, Brasilia, v.19, n.8, p.943-949, 1984.
SANCHEZ, C.A.; BLACKMER, A.M.; HORTON, R.; TMMMONS, D.R. Assessment of errors associated with plot size and lateral movement of nitrogen-15 when studying fertilizer recovery under field conditions. Soil Science, Baltimore, v.144, n.5, p.344-351, 1987.

TAKAHASHI, D.T. Nitrogen field studies with sugarcane. Hawaiian Planters' Record, Honolulu, v.57, n.2, p.198-222, 1964.

TAKAHASHI, D.T. Fate of applied fertilizer nitrogen as determined by the use of ${ }^{15} \mathrm{~N}$. I. Summer and fall plant and a ratoon crops on the Hamakua coast of Hawaii. Hawaiian Planters' Record, Honolulu, v.57, n.3, p.237-266, 1967a.

TAKAHASHI, D.T. Effect of amount and timing on the fate of fertilizer nitrogen in lysimeter studies with ${ }^{15} \mathrm{~N}$. Hawaiian Planters' Record, Honolulu, v.57, n.4, p.292-309, $1967 b$.

TAKAHASHI, D.T. Fate of applied fertilizer nitrogen as determined by the use of ${ }^{15} \mathrm{~N}$. Il. Summer plant and ratoon crops at Hilo, Hawaii. Hawaiian Planters' Record, Honolulu, v.58, n.2, p.13-20, 1969.

TAKAHASHI, D.T. Fate of appplied fertilizer nitrogen as determined by the use of is N. IIl. Summer and winter plant and ratoon crops at two locations on Kauai. Hawaiian Planters' Record, Honolulu, v.58, n.4, p.53-69, 1970.

TRIVELIN, P.C.O.; SALATI, E.; MATSUI, E. Preparo de amostras para análise de ${ }^{15} \mathrm{~N}$ por espectrometria de massa. Piracicaba, CENA, 1973. 41p. (Boletim Técnico, 002).

TRIVELIN, P.C.O.; RODRIGUES, J.C.S., VICTORIA, R.L. Aproveitamento pela soqueira de cana-de-açúcar do nitrogênio dos adubos uréia $\left({ }^{5} \mathrm{~N}\right)$ e aquamônia $\left({ }^{15} \mathrm{~N}\right)$ incorporados ao solo em área fertilizada com vinhaça. In: SEMINÁRIO DE TECNOLOGIA AGRONÔMICA, 3., 1986. Piracicaba. Anais... Piracicaba: Centro de Tecnologia da COPERSUCAR, 1986. p.287-301.

WENDROTH, O.; AL-OMRAN, A.M.; KIRDA, C.; REICHARDT, K.; NIELSEN, D.R. State-space approach to spatial variability of crop yield. Soil Science Society of America Joumal, Madison, v. 56 , n.3, p.801-807, 1992.

WOOD, R.A. The effect of time of application on the utilisation of fertilizer nitrogen by plant cane. In: INTERNATIONAL SOCIETY OF SUGAR CANE TECHNOLOGISTS CONGRESS, 15., 1974. Durbau. Proceedings... Durbau: Hayne et Gibson, 1974. vol.2, p.618-629.

Enviado para publicação em 13.12.1993

Aceito para publicação em 20.04.1994 